S. Bagriy, Cand. Sci. (Geol.), E-mail: gbg2020@ukr.net;

E. Kuzmenko, Dr. Sci. (Geol.-Min.), PROF.,

E-mail: eduard.kuzmenko1@gmail.com; U. Dzoba, Assist. Prof., E-mail: ulianadzoba@gmail.com; Ivano-Frankivsk National Technical University of Oil and Gas, Institute of Tourism and Geosciences, 15 Karpatska Str., Ivano-Frankivsk, 76019, Ukraine

\title{
CORRELATION OF NATURAL PULSED ELECTROMAGNETIC FIELD OF THE EARTH WITH STRESSES AND DEFORMATIONS, WHICH APPEARED IN EXHAUSTED SALT FIELDS IN THE PRECARPATHIANS FOR KARST CREATION FORECASTING
}

\begin{abstract}
(Представлено членом редакційної колегії д-ром геол. наук О.І. Меньшовим)
The problem of solving the ecological and geological issues which arise as the result of working off in natural resources (in particular the deposits of potassium salts) is actual at this time. Specificity is in easy solubility of salts and therefore the creation of artificial cavities and karstic phenomena. The article examines the ways to solve the problems of mapping the salt karst and forecasting creation of dips and subsidence of the earth's surface by the example of Kalush-Holyn potassium salt deposit which is located in Ukrainian Precarpathians. As the basis of the research, the complex geophysical methods were considered. It was proved that the method of natural pulsed electromagnetic field of the Earth (NPEMFE) can be selected as a reliable evaluation method of stress-strain state of rocks and prediction of karst processes and deformations which is associated with the presence of extracting chambers. The article describes the physical preconditions for applying the method, sets out the basic postulates of field intensity anomalies classification and proposes the methodology for depth evaluation. Using the real examples - the profile and planar research of potassium salt deposit - the succes of the NPEMFE method is shown, along with its effectiveness to solve some ecological and geological problems, as well as feasibility of using the method in other areas.
\end{abstract}

Keywords: ecological and geological problem, geophysical methods of research, deposits of salt, natural pulsed electromagnetic field of the earth, karst, subsidence of the earth's surface.

Actuality of the question. One of the most significant manifestations of the impact of mining on the geological environment is the sinking of the earth's surface over mining workings. With the development of this process there is connected the decline in engineering-geological stability of rocks, the decomposition of rock masses occurring over underground workings, the redistribution of tensions around the produced space in the rock massif. Because of the accumulation of the earth's surface over mining, other dangerous processes such as flooding and waterlogging arise, which violate the natural conditions. Within the territory of Ukraine, the total area of cultivated land exceeds $5500 \mathrm{~km}^{2}$, while the settlements and shifts over underground workings are recorded (National report..., 2013). In Ivano-Frankivsk region, within Kalush-Holyn deposit of potassium salts, the area of subsidence is $0.3 \mathrm{~km}^{2}$, the depth ranges from 0.2 to $2.1 \mathrm{~m}$. The destruction of residential and commercial buildings, as well as the formation of numerous subsidence trough (Activation of hazardous exogenous geological processes..., 2019).

Purpose and objectives of the research. The purpose of the study is to determine the state of stresses and deformations of rock masses at the observed sites of Kalush-Holyn potassium salt field by the method of the natural pulsed electromagnetic field of the Earth (NPEMFE), by establishing interconnections between the results of geodetic and geophysical measurements and processing of predictive maps of the state of stresses and deformations of the rocks array. The final stage is the assessment of the risk of subsidence and deformation, as well as providing recommendations on the differentiation of the territory in terms of the possibility of building or the need to eliminate the activity of economic and residential facilities.

Analysis of literary data. Taking into account that the stress state of rocks can occur in different processes and appearances and depend simultaneously on a large number of factors, there is no single theory of NPEMFE for today. However, in some cases, A.A. Vorobyov and V.M. Salomatin presented the volume of experimental laboratory studies and measurement results of NPEMFE in various geological studies (Vorobyov, 1971, 1980; Salomatin et al., 1991).
New principles of data processing systems of NPEMFE in the studies of the stress-strain state of rocks in the shifting areas of Transcarpathia are described in the works of V.D. Cheban (Cheban, 2002). A.V. Bezsmertnyi proposed the use of NPEMFE in combination with other geophysical methods for studying landslides on the southern coast of Crimea (Bezsmertnyi, 2004). S.P. Kovalchuk describes the application of the method of NPEMFE in detail and describes the results of data processing on displacements and the search for catacombs in Odessa region (Kovalchuk, 2003).

Also, the problem of using the NPEMFE method in combination with other geophysical methods for forecasting exogenous geological processes is dealt with by E.D. Kuzmenko (Kuzmenko et al., 2009). In the works, the calculation of the probabilistic criterion for the predicted estimation of landslide sections is suggested and the possibility of using geophysical methods for determining the stability of landslide slopes is proved. Positive results of the NPEMFE method are used to outline underground galleries, mine workings, karst dips (Khmara et al., 2008; Bagriy, 2016). In the salt deposits in Ukraine, a complex of geophysical methods is used for studying salt karsts: gravimetry, probing by the formation of an electromagnetic field (ZS), by the method of the natural pulsed electromagnetic field of the Earth (NPEMFE) (Kuzmenko et al., 2017, 2018; Shurovsky et al., 2012, 2013; Deshchytsia et al., 2016; Maksymchuk et al., 2019).

The method of NPEMFE has also been applied successfully for the search for hydrocarbon pools (Malyshkov et al., 2016), the methodology for interpreting the NPEMFE anomalies associated with the appearance of earthquakes (Hao et al., 2017), and the search for geodynamically active faults to improve the safety of mining operations in ore deposits (Belova et al., 2019) and others.

Characteristics of the study area. From the geological point of view, salt deposits of the Carpathian region are located in the area of the spread of evaporate Neogene deposits in the Precarpathian and Transcarpathian marginal deflections. The location of salt deposits and salt manifestations are depicted in Fig. 1. 


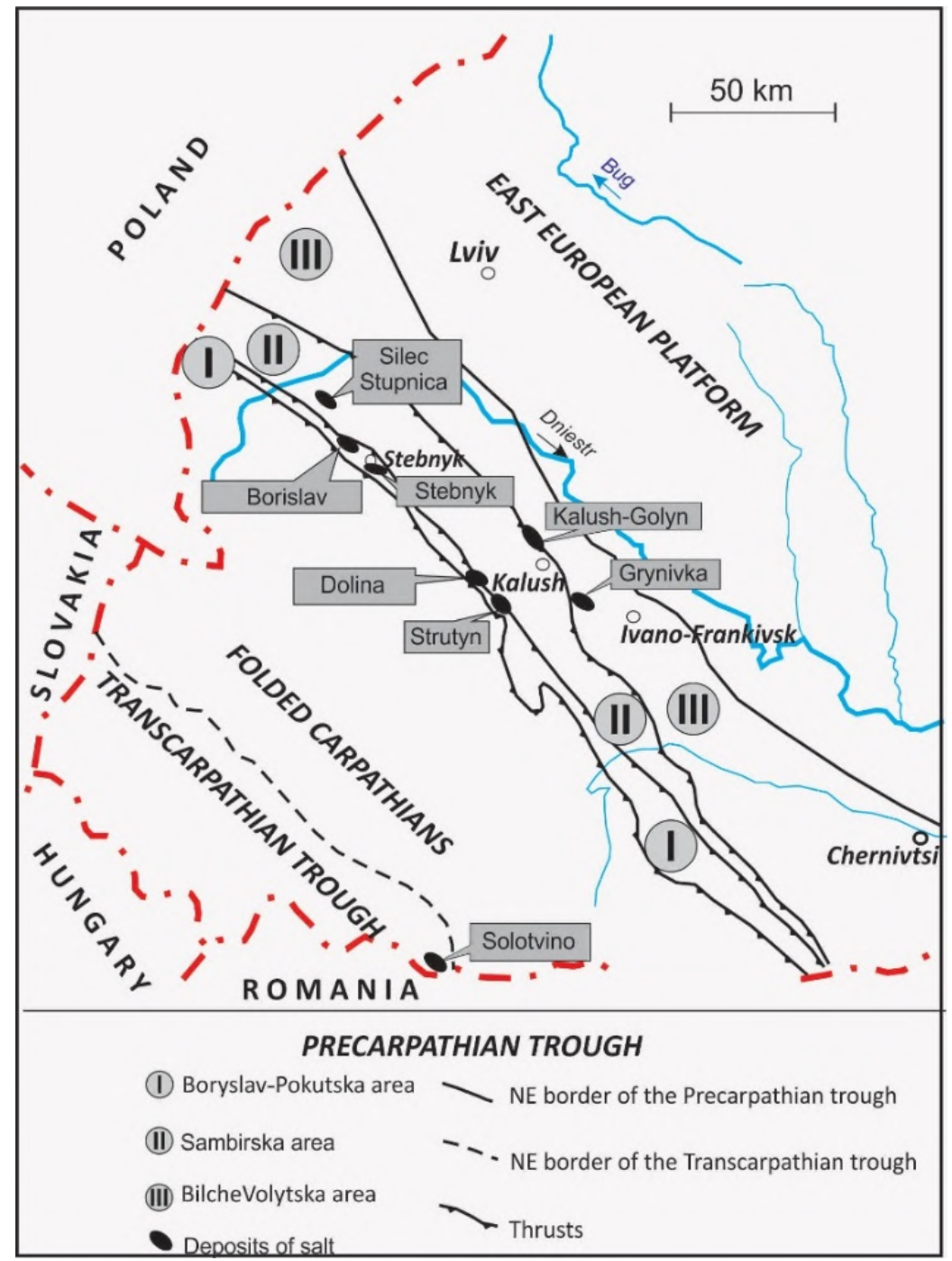

Fig. 1. Location of salt deposits and salt manifestations in the western part of Ukraine

Salt rocks have the sub-Carpathian stretch of at least $1000 \mathrm{~km}$ (Poland, Ukraine, Romania) with the width of several tens of kilometres.

In the Carpathian region, there are three geological formations, confined to Neogene deposits. The first formation is connected with the inner zone (BoryslavPokuttia), the second and third - with the outer zone (Sambir and Bilche-Volitska) deflection. In Ukraine, in the Carpathian region, there are two large deposits of potassium salt (each one of them is over 100 million tons): Stebnyk and KalushHolyn. The first refers to the inner zone, the second - to the external zone. A typical lithologic-stratigraphic section of Kalush-Holyn deposit is presented in Fig. 2.

In connection with changes in the sea level and depending on the frequency of alternation of Neogene deposits, one can assume that there are several salt deposits. The depth of the salt chambers produced in the lower layers is $300-400 \mathrm{~m}$. The changes in deposits from subhorizontal to sub-vertical (the latter characteristic of Stebnyk deposit) are related to the post-neogene complex formation. Salt deposits are mostly surrounded by breccia. The presence of the upper part of the so-called "gypsumclay hat" is due to weathering processes. The extraction of minerals on Kalush-Holyn field occurred in 1867-1995 in two ways: surface and underground. The surface method is represented by Dombrovskyi quarry, which after the end of operation had a volume of about 52 million $\mathrm{m}^{3}$. The produced underground chambers of Kalush mine (area 7.4 million $\mathrm{m}^{3}$ ), Novo-Holyn (area 12.1 million $\mathrm{m}^{3}$ ) and Holyn (area 1.7 million $\mathrm{m}^{3}$ ) were only partially filled with solid material. Most of the voids are filled with unsweetened solutions of brine. This way of eliminating the voids does not guarantee the stability of the rock massif, in particular the rocks between and over the cameras. As a result, the surface of the earth can settle down with subsequent flooding and the formation of salt lakes. Geodetic and geophysical methods were used to determine the dynamics of precipitation and its prediction in time and space.

Tasks of the method of NPEMFE. Physical basis of the method. The method of NPEMFE is increasingly used to solve the following engineering, geological and environmental tasks:

- qualitative estimation of the total natural field of mechanical stress and tracking its dynamics;

- operational detection and prognosis of dangerous exogenous phenomena and geological processes;

- determination of the moment of activation of geodynamic processes, reflection and characteristics of zones of dissolution;

- status monitoring of residential buildings, utility rooms and infrastructure objects in order to detect possible deformations of foundations and walls of structures;

- assessing the state of strain and deformation of the dams and other hydrodynamic structures, defect detection and water filtration.

The method is based on the processes of generating minerals of the pulsed electromagnetic field during the change in the state of the rock mass. 


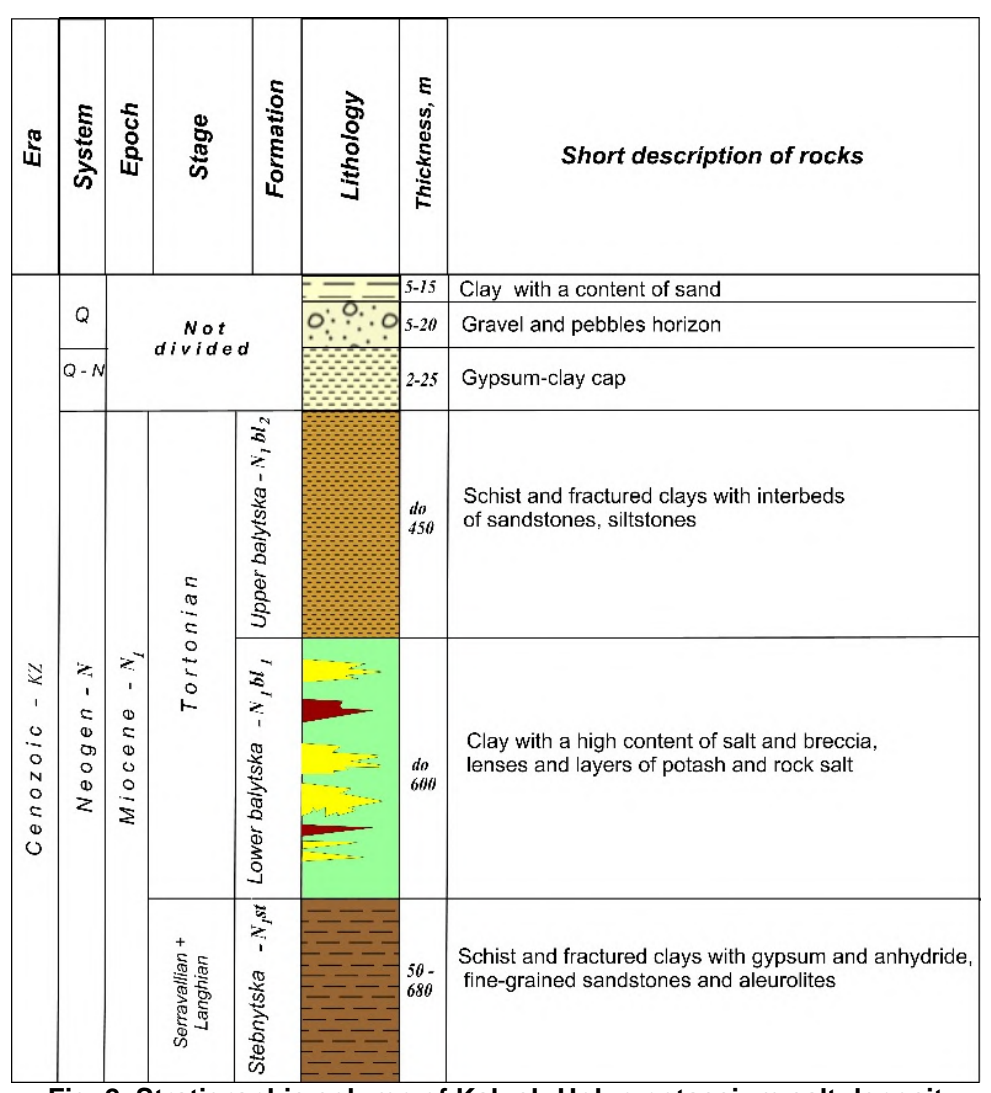

Fig. 2. Stratigraphic column of Kalush-Holyn potassium salt deposit

The structure of each solid is not perfect. This is especially true of the arrays and compounds occurring in nature minerals and rocks, the composition of which consists mainly of dielectrics containing impurities, cracks, pores and other defects. The presence of an external source of energy causes the excitement of the internal structure of the body.

At the same time, the system proceeds from the state of equilibrium, and the excess of electromagnetic energy can be emitted. The transition from one state to another occurs through various changes, the most interesting of which are mechanical-electrical transformations. In the field of a variable mechanical stress, an excitation of a crystal lattice occurs. The mineral skeleton in the saturated and partially saturated rocks is the first to engage in mechanical and electrical transformations. In the clayey rocks, in addition to the cracks and deformations of the structures of the mountain skeleton, double electric layers are involved in the process of formation of pulsed electromagnetic fields. Intensive liquid filtration in capillaries, pores and other cavities is accompanied by polarization. Physical nature of phenomena forming pulsed fields is quite diverse. The founder of this method is considered to be the well-known physicist A. Vorobyov, who, introducing the concept of the "natural pulsed electromagnetic field of the Earth", understood a whole set of electrical discharges that are constantly present in all layers of our planet and in outer space (Vorobyov, 1980).

The intensity of geoelectric processes depends on many factors: the composition and properties of the rocks of different horizons, the degree of their activity, the thickness of the deformed masses, the nature of deformations. The difficult state of the stresses of a rock massif causes different possibilities of the course of mechanical and electrical phenomena. Because of this reason, these phenomena in the literature are considered separately. Unlike other geophysical methods, there is no single theory in the NPEMFE method.

For objects of natural origin, which have a complex structure and geological history, it is difficult to determine a certain mechanism of mechanical and electrical transformations. Therefore, in the above-mentioned works, the correlation of the field strength for each parameter (affecting the field through initiation or intensification) is shown using qualitative and descriptive research methods. These studies are confirmed by a large empirical and experimental basis, which is consistent with the general physical and mathematical theorems.

The theoretical equations presented in A. Vorobyov's work give a general idea of the multifactorial nature of the electromagnetic radiation formation process. These formulas can in no way be the basis for solving the simple or reciprocal geophysical problem, since such templates do not exist for NPEMFEs. For this reason, it should be assumed that the NPEMFE method is a qualitative method, established on the basis of comparison of geological phenomena and corresponding field changes according to the principle "more or less", based on qualitative dependence of geological changes and electromagnetic field.

Among the fundamental works in the area of geological studies of the nature of the electromagnetic field in the earth's crust one should mention the works of B. Tarasov and his colleagues (Tarasov et al., 1983). As for the theoretical basis for the emergence of natural geoelectric potentials, the article by V. Ivanov (Ivanov et al., 1991) is the most informative and worth attention.

The basic idea is that stationary gradient geomechanical fields contain stationary flows of charged defects of internal structures represented in the form of ion deficiency (anions or cations). In the state of thermodynamic equilibrium, charged particles are compensated by charges with the opposite sign, indicating that the field does not exist. After the load is added, the charge equilibrium is disturbed, since there is a directed distribution of defects and their separation from the compensating charge cloud. This process causes the generation of electric current to which a certain electric potential corresponds. 
The researches represented in the literature and the results obtained are theoretical substantiation and practical evidence that electromagnetic signals are generated in rocks of different mineralogical composition and with different properties (mechanical and electrical) at certain stages of microdeformation. In addition, the intensity of electromagnetic radiation at different types of loads increases with increasing content of dielectric minerals in rocks. The transition from one phase of stress / deformation to another is characterized by the extremums of the frequencies of electromagnetic pulses. The authors of this article pay particular attention to the fact that mechanical and electrical transformations of energy and pulsed radiation require a change in the state of mechanical stress over a period of time.

Lately, the researchers of NPEMFE have limited themselves to solving specific practical tasks concerning data processing and the specifics of interpretation in different geological conditions (Dolgii et al., 2015; Dovbnich et al., 2012; Dodatko et al., 2013).

Methodology and measurement methodology. Practical implementation of the NPEMFE method is carried out in accordance with a specially developed method for the use of portable devices of indicator type.

The most commonly used in Ukraine is a relatively easy to use and inexpensive device for estimating the intensity of the flux (frequency of occurrence) of natural pulses of an electromagnetic field - a radio frequency indicator of a state of stress and deformation of rocks (RHINDS). The indicator was designed and manufactured by the Western Ukrainian Geophysical Expedition and the Scientific-Production Enterprise "Intellect" (Lviv). In addition, the devices "APOGEY" (Kyiv) and "ADONIS-32" (Simferopol), which were produced in different years in small quantities, are also used.

The method and way of performing work in the configuration of devices and work with them require the following sequence:

- division of devices according to the performed function. One device is set to the base (reference), and the other fixes the value of the field. The base unit is installed in a geologically homogeneous and immovable part of the measuring zone. Changes in field strength in this device are caused by various types of interference - space, atmospheric, induced by human. The meter operates in the usual geophysical profiling.

- device synchronization. Before starting measurements in the testing area, it is necessary to ensure simultaneous registration of the field. To do this, you need to connect the devices with a cable. Then set the same date and time (hour, minute, second) on each device.

- selection and setting of frequency range. The device can operate in the range of $2-50 \mathrm{kHz}$, that is, all pulses of the field in a given range will be written as the total value - the number of pulses per unit time. You can limit the registration of smaller intervals (but not less than $5 \mathrm{kHz}$ ) - adapting to specific tasks. Increasing the frequency leads to a decrease in the depth of the range, that is, the choice of different frequency ranges allows you to control the range of depth.

- setting the time and range of measurement. Measurement interval is the period during which a device performs a measurement. This parameter depends on the time of measurement on the profile and the distance between the profiles, since during this time the device needs to be moved to the next measurement point. The measurement cycle is constant for both devices and is determined by an empirical method with a certain margin. Measurements on each device are carried out in each cycle.

- setting the pulse accumulation mode. In order to minimize the role of random signals, the device has a function of accumulation of 1 to 15 full measurements over a period of time. For example, you can set the mode of 15 measurements for 15 seconds (1 measurement per second), you can also set the mode of 10 measurements in 20 seconds ( 1 measurement in 2 seconds), etc. The duration of the measurement - 1,2,10,60 seconds should be taken into account. In the final result, we determine the total number of pulses measured over a period of time, that is, the number of pulses per second.

- orientation of antennas. According to the technical documentation, field registration is carried out simultaneously for three antennas: two horizontal - $X$ and $Y$ and vertical $Z$. The antennas $X$ and $Y$ are oriented along the directions south-north and west-east. When displaying specific objects, one of the antennas should be directed along the other, and the other - through the length of the geological elements. For example, in the case of a bias, one antenna should be directed along the slope, and the other one is across. In each of the examples above, the antennas are oriented identically for each time.

- the intensity of the radiation of the electromagnetic field is denoted by $I_{X}, I_{Y}, I_{Z}$..Additionally calculate the total intensity (vector of the full field), taking into account the interaction of each of the components according to the formula $T=\sqrt{I_{x}^{2}+I_{y}^{2}+I_{z}^{2}}$. For each antenna is measured the number of impulses per unit time (imp/s).

- data recording. Data recording from each antenna of the device is carried out through the corresponding modules installed in the device. Saved information can be read on the computer with the added software.

Requirements for monitoring network NPEMFE are similar to general requirements for geophysical profiling (electric, magnetometric, gravimetric) in the profile or planar versions.

The end results of the work are the graphs and maps of the intensity of electromagnetic radiation for each antenna. Anomalies from horizontal antennas usually reflect anisotropic properties on a plane, and the vertical antenna records an integrated signal that is transmitted from all sides.

At the stage of preparing for the construction of charts and maps from the obtained values of field strength, it is necessary to deduct the values of variations that the stationary device fixes. As a result, we get a signal without regional interference (characteristic of this area). During the interpretation, maps of anisotropy coefficients are also calculated, which are calculated as the ratio of signals from the horizontal components $\left(I_{x} / I_{y}\right.$ or $I_{y} / I_{x}$ ) for each observation point. When taking into account anisotropy coefficients, the level of obstacles associated with geological inhomogeneities is significantly reduced.

The resulting graphs and maps of NPEMFE in the future can be considered as an independent source of information or used as part of a complex study (Kuzmenko et al., 2009).

Interpretation of NPEMFE. Theoretical models. Prediction of breed deformations based on NPEMFE data can be based on the following principles:

- estimation of the state of stresses of the mountain mass and prediction of conditions for its possible transition to a critical state;

- determination of permanent deformations in rocks and prediction of their transition to the phase of destruction;

- monitoring deformation processes to protect existing objects from destructive effects.

There is no doubt that the methods based on the study of the laws of changes in the properties of rocks are most 
useful in predicting, since they provide information on the phenomena that precede the visible deformation of rocks. The application of the NPEMFE method contributes to the effective solution of these problems, as evidenced by the multifactorial nature of the processes accompanied by pulsed electromagnetic radiation. This is confirmed by a formula that makes it possible to understand the physics of the process, but it can not be used for modeling (Kuzmenko et al., 2018).

This is due to the fact that the values of the parameters in these formulas are unknown and, in theory, can vary in considerable limits. Therefore, from a qualitative point of view, it is necessary to consider possible inaccuracies and to classify them under certain conditions.
The distribution of mechanical stresses associated with mining is given in (Fig. 3). The processes forming the pressure of the mountain mass include:

- deformation;

- movement and destruction of elements of the surface of the earth;

- the interaction of elements of the array with buildings and structures.

- The main factor causing pressure in the mountain mass is gravity. Other factors having different probabilities of occurrence, duration and strength include:

- tectonic (geodynamic) processes;

- production activity related to the extraction of minerals;

- the presence of underground and terrestrial facilities.

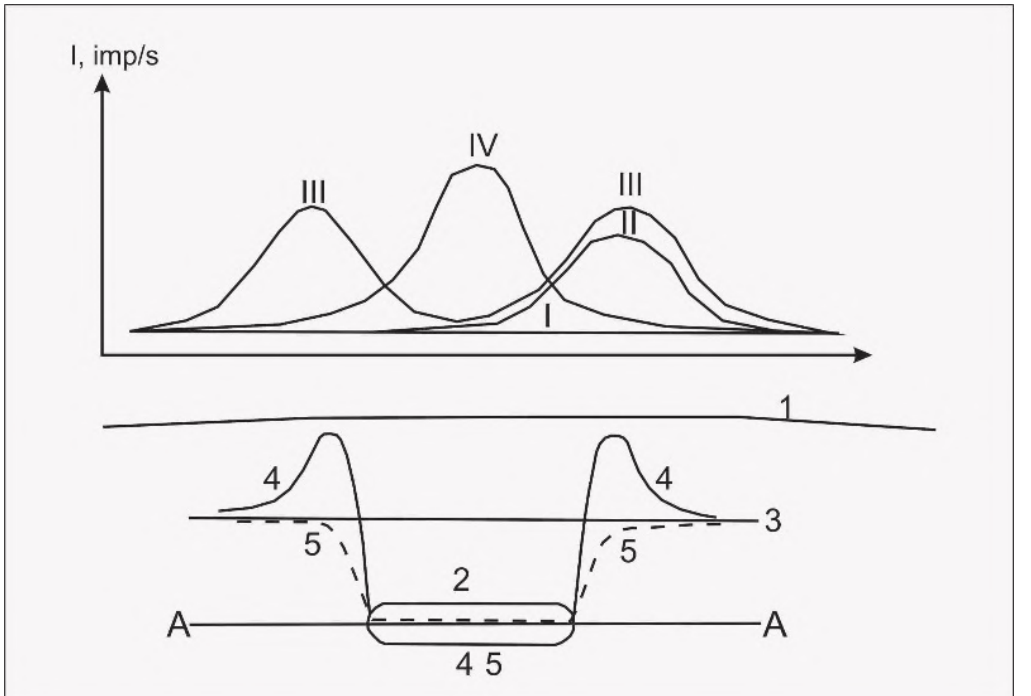

Fig. 3. The changing of mechanical tension distribution due to mining development:

1 - terrestrial surface; 2 - underground mine working; 3 - vertical and horizontal tension at points of straight AA before the development; 4 and 5 - respectively vertical and horizontal tension at points of straight AA after the development. I - IV - NPEMFE curves

The intensity curves of NPEMFE in pulses per second for various possible situations that occur in practice during surveillance are shown in Fig. 3 . In the presence of rocks without any changes in static pressure in time, we obtain curve I. In the case of a rock mass change due to the deformation of any cell chambers (for example, the right to the figure) we obtain the curve II, and all groups are deformed - curve III. In the presence of additional intensions over the sloping camera, we obtain the curve IV. Obviously, combinations of these situations can be ruled out. In addition, additional signals from NPEMFE are possible with a partial understanding of the solar breccias and, accordingly, deformation of the rock massif.

In the initial stages of the development of deformation, dislocation and relaxation of arrays, changing the mountains with the help of electrical transformations will be recorded only in the NPEMFE field. This means that only this method can be used for forecasting. At the following stages, the subsidence of the earth's part is observed in the form of isometric multitudes, which to some extent undergo corrections from the anomaly of NPEMFE.

Results of research of NPEMFE. Geophysical surveys were carried out at all mine fields of Kalush-Holyn field. Many geophysical data were collected for this area. The majority of the sites used the method of NPEMFE, as well as geodetic measurements of the surface of the Earth, which had a monitoring character, were performed.

Below is an analysis of NPEMFE materials for the following elements: profiling, surface surveys, recurrent regime observations. The local elements for the selected sections of the profiles are presented in such a way as to show the anomalies of the intensity of the electromagnetic field over the mining structures or complexes of structures (Fig. 4). To demonstrate the intensity, the total intensity vector I, which contains information from all antennas, is taken.

Anomalies on Fig. 4, a-d fully correspond to model curves I-IV (Fig. 3). In the presence of a series of cameras, they should be considered as one large cavity and the anomaly will reflect the total effect. The curves in Figure 4, e$f$ are confirmation of this, where abnormal effects in the central part and extreme values over the cameras are observed. It should be borne in mind that these significant violations of the intensity of radiation correspond to the development of sections of dissolution in the upper part of the section at the active stage of precipitation.

We take 4 as an example to create a model for qualitative interpretation of NPEMFE data and, accordingly, the classification of abnormal violations. It is advisable to consider the compatibility of types of anomalies of NPEMFE with the stages of subsidence. Next Tab. 1 shows the sequence of stages of activity of the earth surface sediments, which is determined on Fig. the basis of comparison of geophysical and geodetic measurements.

The initial stage is characterized by small precipitation (up to $1 \mathrm{~m}$ ) at a rate of $0-20 \mathrm{~mm} /$ year and the absence or presence of individual karst craters. At the stage of active sedimentation, the maximum speed increases to hundreds of millimeters per year, and the maximum precipitation reaches several meters per year. In the central part of the sediment, lakes are formed, and in the surrounding areas 
there are numerous karst craters and dips. At the final stage, the rate of precipitation decreases significantly. Each of these stages is accompanied by the development of a certain type of anomalies of NPEMFE.
For the proposed methodology of research, it is necessary to introduce another phase, which precedes the initial stage. This stage was introduced to determine the implicit (or hidden) processes of changing the stresses and deformations of rocks.
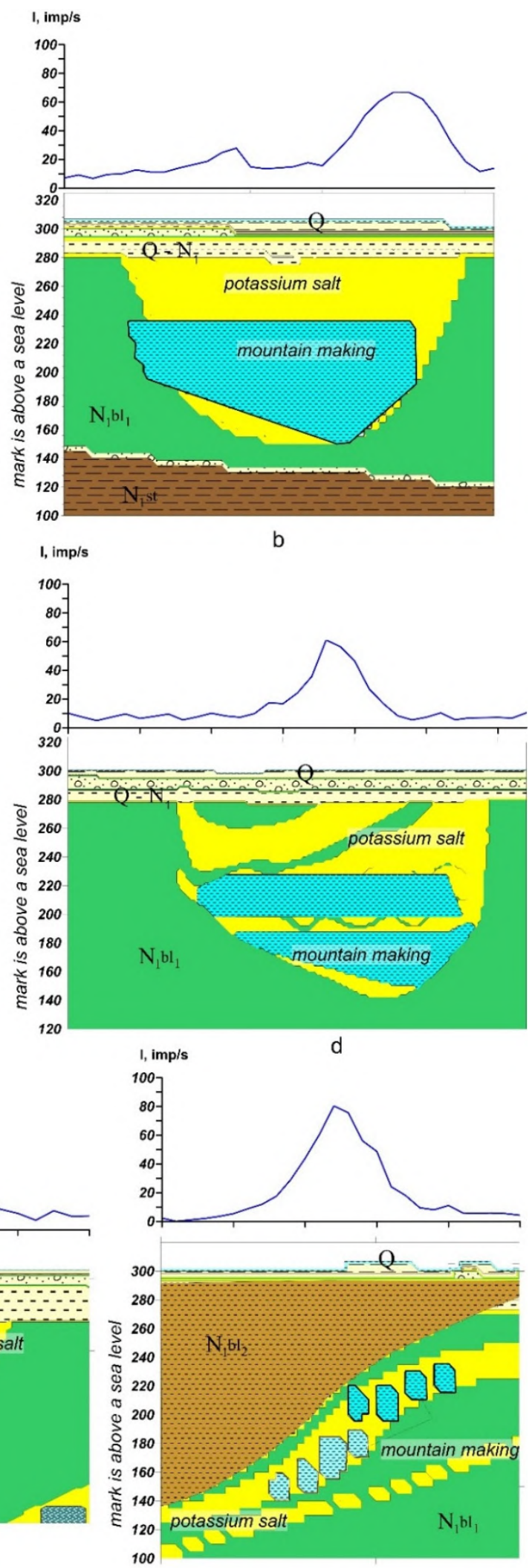

$f$

Fig. 4. Fragments of geological models and corresponding curves NPEMFE:

$a, b, c, d$ - one cavity: $a$ - there is no change in static pressure over time, b-deformation of the right wall cavity, $c$ - deformation of walls, $d$-tensions over the ceiling cavity; e, $f$-complex cavities: $e$ - anomalies in marginal areas, $f$-central anomaly 
Table 1

Conformity of NPEMFE anomalies to the stages of subsidence in Kalush-Holyn deposit

\begin{tabular}{|c|c|c|c|c|c|c|c|c|c|c|c|}
\hline \multirow{3}{*}{ Deposit } & \multirow{3}{*}{\multicolumn{2}{|c|}{ Deposit field, area }} & \multirow{3}{*}{$\begin{array}{c}\text { Maximum } \\
\text { value of } \\
\text { surface } \\
\text { subsidence, } \\
{[\mathrm{m}]}\end{array}$} & \multirow{3}{*}{$\begin{array}{c}\text { Maximum } \\
\text { speed of } \\
\text { subsidence, } \\
\text { [mm/year] }\end{array}$} & \multirow{3}{*}{$\begin{array}{l}\text { Stage of } \\
\text { subsidence }\end{array}$} & \multicolumn{6}{|c|}{ Characteris tics of NPEMFE anomalies } \\
\hline & & & & & & & On map & & On r & tance pro & \\
\hline & & & & & & Intensity & Size & Shape & Intensity & Size & Shape \\
\hline «Kalush» & \multicolumn{2}{|c|}{ Hotin sylvinite field } & 2.8 & $211 \mathrm{~mm} /$ year & attenuation & major & major & $\begin{array}{l}\text { circular, } \\
\text { isometric }\end{array}$ & \multicolumn{3}{|c|}{ data a vailable } \\
\hline \multirow{4}{*}{$\begin{array}{l}\text { «Nova } \\
\text { Holyn» }\end{array}$} & \multirow{2}{*}{$\begin{array}{c}\text { Eastern } \\
\text { Holyn }\end{array}$} & Western part & \multirow{2}{*}{0.385} & \multirow{2}{*}{$17 \mathrm{~mm} / \mathrm{year}$} & initial & medium & medium & \multirow{2}{*}{$\begin{array}{l}\text { circular, } \\
\text { isometric }\end{array}$} & \multirow{2}{*}{ all } & small & \multirow{2}{*}{ Ienear } \\
\hline & & Eastern part & & & active & major & major & & & medium & \\
\hline & \multirow{2}{*}{$\begin{array}{c}\text { Kalush- } \\
\text { Sivka }\end{array}$} & Northern part & 0 & - & null & small & small & all & small & small & \multirow[b]{2}{*}{ lenear } \\
\hline & & $\begin{array}{l}\text { Southern } \\
\text { part }\end{array}$ & 0.255 & $11 \mathrm{~mm} /$ year & initial & medium & small & isometric & medium & medium & \\
\hline «Holyn» & \multicolumn{2}{|c|}{ Holyn } & 1.37 & $24 \mathrm{~mm} /$ year & attenuation & \multicolumn{3}{|c|}{ data available } & major & $\begin{array}{l}\text { medium, } \\
\text { major }\end{array}$ & lenear \\
\hline
\end{tabular}

The difference between this stage and the other is that the fact that the deformation is not fixed with the help of geodetic measurements, that is, the deposition has not occurred yet, but will necessarily occur in the future on the plane or along the line of violation of the intensity of the field. In this sense, the results of the NPEMFE method can be considered as predictive of increasing stresses and deformations. The said anomalous phase of NPEMFE is called pre-primary.
Planar (superficial) studies in the mine fields Khotyn, Sivka-Kaluska, Holyn testify to the effectiveness of using the method to determine the stress state and deformations. Violations of the intensity of the electromagnetic field may precede precipitation or occur simultaneously, in parallel. The typical confirmation of this is the results of field geodetic observations and the results of NPEMFE research on the Novo-Holyn mine field (Fig. 5).

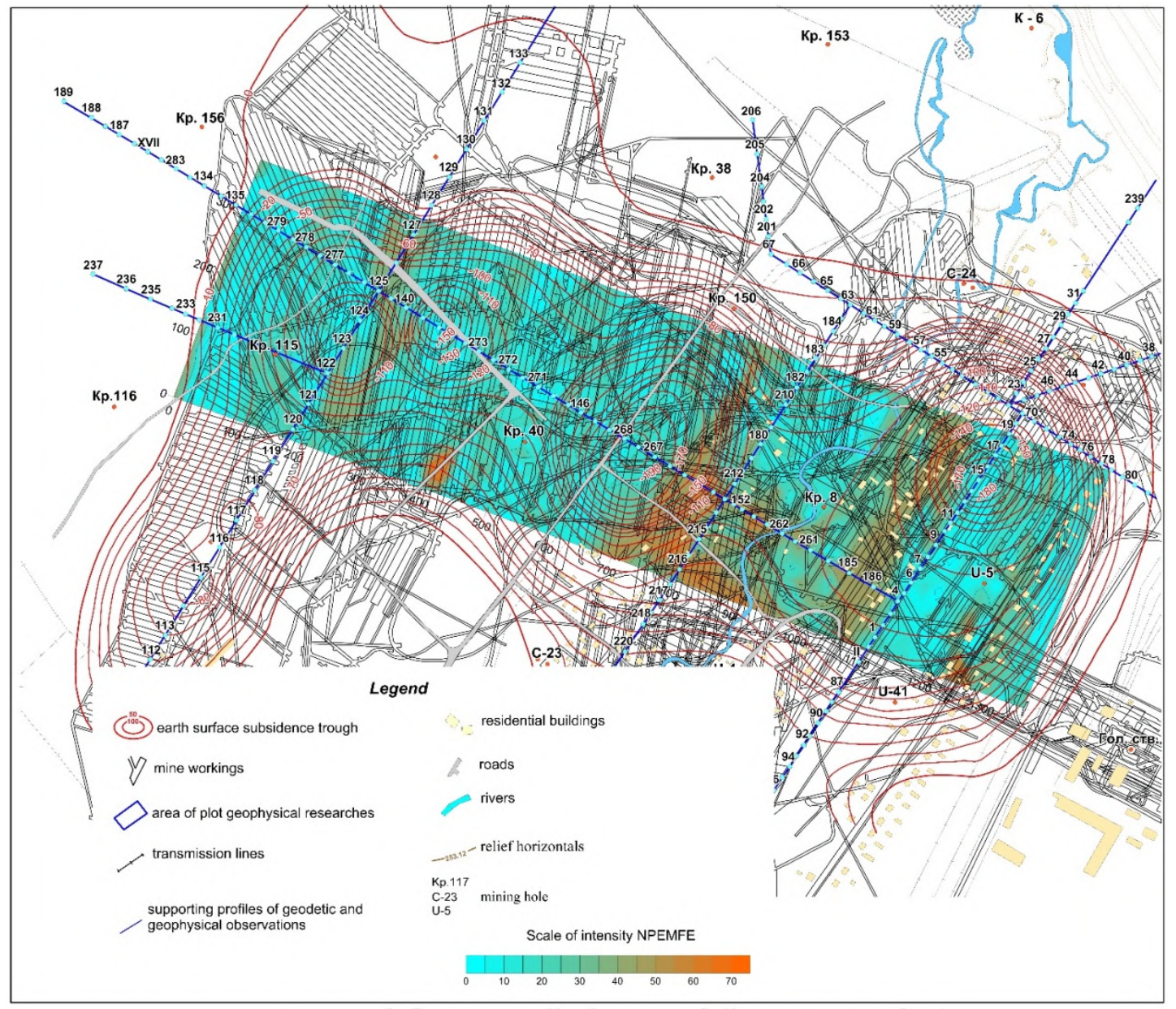

Fig. 5. Results of profile geodetic and flat researches NPEMFE. The deposit "Nova Holyn"

The effectiveness and reliability of the NPEMFE method is further confirmed by the results of monitoring observations (Fig. 6). In 2005, three zones with abnormal values of about 25-50 imp/s were detected over the cameras, which were responsible for the presence of dynamic deformations near the walls and over the roof of the chambers. At the same time, the subsidence of the earth's surface was not fixed, that is, there was a "pre-initial" stage, indicating the beginning of a violation of the state of rocks, which has not been observed on the Earth's surface yet. In 2012, the 
deformation area was formed that was accompanied by precipitation at an initial stage. In 2013 , the intensity of the anomalies of the electromagnetic field significantly increased to $65 \mathrm{imp} / \mathrm{s}$, while maintaining the area of distribution of the previous year, and the initial stage of subsidence moved into an active stage. The presence of certain field anomalies in accordance with the data of gravimetry is due to the development of areas of dissolution associated with the processes of deformation, and, probably, with the washing of salt from rocks in the infiltration of surface water in the chamber. It should also be noted that the intensity of the field on the left side of the profile is much higher compared to the initial measurements in 2005. This indicates the development of deformation processes due to the presence of the lower row of chambers.

As the result of the analysis of the data presented in Figures 5-6, the problem of assessing the environmental risk in the area can be solved. As the result, it is possible to answer the question of a balanced and diversified approach to preventive actions, in particular the need to resettle residents from territories threatened by the formation of karst craters and the development of processes of subsidence of the earth's surface.
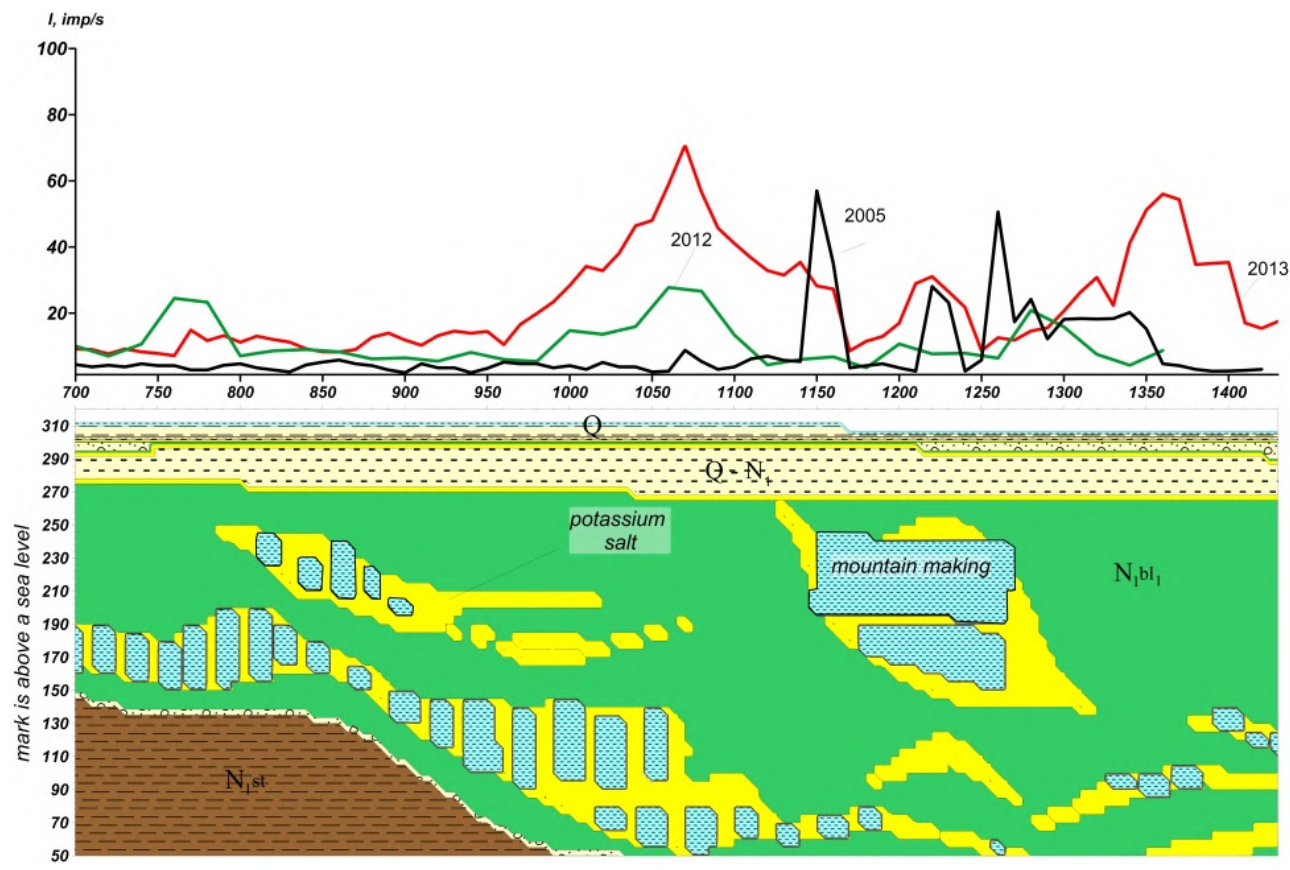

Fig. 6. Monitoring by NPEMFE observation method

Conclusions. Summing up, one can distinguish the following conclusions.

1. The problem of predicting the development of salt karsts and deformation processes on waste deposits of potassium and rock salt is relevant and well-known. In particular, in the Carpathian region of Ukraine, this problem appeared on the territories of the Solotvyno rock salt (Transcarpathia), Stebnyk and Kalush deposits of potassium salt (Precarpathians).

2. One of the priority directions of research of salt karsts and prediction of surface sedimentation and karst phenomena is the use of geodetic measurements and complex geophysical researches: vertical electrical probing, sounding of the formation of an electromagnetic field, tomography of electro-aerial, georadar measurements, natural pulsed electromagnetic field of the earth, gravimetry. However, the named complex is burdensome and requires considerable material costs.

3. The results of the study showed that in the first stage of this geophysical complex it is expedient to use the NPEMFE method, which is based on the registration of the intensity of the pulsed electromagnetic field arising as the result of the mechano-electric transformations in the dynamic changes of the stressed state of rocks, leading to their deformation.

4. The method of NPEMFE should be considered predictable, since it provides information on the development of the deposition of the earth's surface and failure phenomena even before they are fixed by geodetic measurements. Similarly, information can be obtained by other methods of electrometry by changes in electric resistance and gravimetry by changing the density of rocks. However, the NPEMFE method should be considered as the mobility of execution and informativeness by the express method. Other methods, especially gravimetric and electrometric, should be considered as methods of detailing.

5. The advantages of the NPEMFE method, in addition to the forecast of the geodynamic process development, are the possibility of differentiation of the zones of subsidence of the Earth's surface, as well as in identifying the stages of deformation or subsidence - pre-primary, initial, active, final.

6 . The article describes the classification characteristics of the NPEMFE anomalies for the first time in accordance with the degree of ecological-geological risk, coordinated with the causes and characteristics of deformation processes, formed the criteria for qualitative interpretation for examples of specific geological situations, and also demonstrated the effectiveness of the method for KalushHolyn potassium salt deposit in Ukrainian Precarpathians.

7. It is confirmed that the NPEMFE method is promising for the use on other territories to assess the ecological risk associated with the development of exogenous geological processes (karst, landslide) in conditions of violation of the primary state of rocks due to dynamic changes.

\section{Список використаних джерел}

Активізація небезпечних екзогенних геологічних процесів за даними моніторингу ЕГП. (2019). Державна служба геології та надр України. Київ. Випуск XVI. Отримано 3 http://www.geoinf.kiev.ua/SZHORICHNYK 2019.pd

Багрій, С.М. (2016). Геофізичний моніторинг геологічного середовища в межах родовищ калійної солі (на прикладі Калуш-Голинського родовища). Дис. ... канд. геол. наук: 04.00.22. Івано-Франків. нац. техн. ун-т нафти і газу. Івано-Франківськ. 
Бессмертний, А.Ф. (2004). Комплексные геофизические исследования оползней и построение прогнозных моделей их активности (на примере Южного берега Крыма). Дис. ... канд. геол. наук: 01.04.12. Симферополь.

Воробьев, А.А. (1971). Физические условия залегания вещества в земных недрах. Ч. 1. Томск: Изд-во Томского политехн. ин-та.

Воробьев, А.А. (1980). Равновесие и преобразование видов энергии в недрах. Томск: Изд-во Томского ун-та.

Дещиця, С., Підвірний, О., Романюк, О., Садовий, Ю., Коляденко, В., Савків, Л., Мищишин, Ю. (2016). Оцінка стану екологічно проблемних об'єктів Калуського гірничопромислового району електромагнітними методами та їх моніторинг. Nauka innov., 12(5), 47-59.

Довбніч, М.М., Стовас, Г.М., Канін, В.О. (2012). Спостереження ПІЕМПЗ і вертикального градієнту магнітного поля Землі на полі шахти ім. О.Ф. Засядька. Наукові праці Укр НДМІ НАН України, 10, 342-348.

Долгий, М.Е., Катаев, С.Г. (2015). Исследование естественного импульсного электромагнитного поля Земли. Вестник Томск. гос. ун-та. Матем. и мех., 2(34), 61-70. DOI: https://doi.org/10.17223/19988621/34/6

Иванов, В., Тарасов, Б., Кузьменко, Е. Гордийчук, Н. (1991). О геомеханической природе потенциалов электрического поля в земной коре. Изв. ВУЗов. Геология и разведка, 3, 101-104.

Ковальчук, С.П. (2003). Поставь свой дом правильно (практика геофизического метода ЕИЭМПЗ). Одесса: Черноморье.

Кузьменко, Е.Д., Багрій, С.М., Чепурний, І.В., Штогрин, М.В. (2017). Оцінка небезпеки приповерхневих деформацій гірських порід у межах Стебницького калійного родовища методом ПІЕМПЗ. Геодинаміка, 1(22), 98-113.

Кузьменко, Е.Д., Безсмертний, А.Ф., Вдовина, О.П., Крив'юк, І.В., Чебан, В.Д., Штогрин, Л.В. (2009). Дослідження зсувних процесів геофізичними методами. За ред. Е.Д. Кузьменка. Івано-Франківськ: ІФНТУНГ.

Максимчук, В., Сапужак, О., Дещиця, С., Ладанівський, Б., Романюк, О., Коляденко, В. (2019). Дослідження карстопровальних процесів на території Стебницького родовища калійних солей методами електророзвідки. Геофорум-2019. Збірник тез доповідей 24-ї Міжнародної науковотехнічної конферениії, Львів, 37-38.

Національна доповідь про стан техногенної та природної безпеки в Україні у 2012 р. (2013). Державне підприємство "Агентство "Чорнобильінформ".

Саломатин, В.Н., Мастов, Ш.Р., Защинский, Л.А. (1991). Методические рекомендации по изучению напряженного состояния пород методом регистрации естественного импульсного электромагнитного поля Земли (ЕИЭМПЗ). Симферополь : КИПКС, КОСНИО.

Тарасов, Б., Дырдин, В., Иванов, В.В. (1983). Геоэлектрический контроль состояния массивов. Москва: Недра.

Хмара, І. Є., Кузьменко, Е. Д., Багрій, С.М. та ін. (2008). Проведення моніторингових спостережень над шахтними полями Калуш-Голинського родовища калійних солей. Звіт про науково-дослідну роботу. № ДР 0108U007562, Інв. №0309U00296. Калуш: ДП "НДІ Галургії".

Чебан, В.Д. (2002). Комплекс геофізичних методів прогнозування зсувів на прикладі Закарпаття. Дис. ... канд. геол. наук: 04.00.22. Івано-Франківськ: ІФНТУНГ.

Шуровський, О.Д., Аникеев, С.Г., Шамотко, В.И., Дещиця, С.А. (2013). Геофизический мониторинг геологической среды для решения экологических проблем в пределах агломерации г. Калуша. Горный журнал, 12, 99-104.

Шуровський, О.Д., Анікеєв, С.Г., Шамотко, В.І., Дещиця, С.А., Ніколаєнко, О.А., Поплюйко, А.Г. (2012). Геофізичний моніторинг еконебезпечних геологічних процесів в агломерації м. Калуша. Мінеральні ресурси України, 2, 31-38.

Belova, M., lakovleva, E., Popov, A. (2019). Mining and environmental monitoring at open-pit mineral deposits. Journal of Ecological Engineering, 20(5), 172-178. doi:10.12911/22998993/105438

Dodatko, A.D., Zmiyevskaya, K.O., Kozar, N.A. (2013). Detalization of tectonic features of the sergeyevskoye deposit by means of the method of natural impulse electromagnetic field of the earth. Naukovyi Visnyk Natsionalnoho Hirnychoho Universytetu, 1, 5-10.

Hao, G., Bai, Y., Wu, M., Wang, W., Liu, H. (2018). Time-frequency analysis of the earth's natural pulse electromagnetic field before earthquake based on BSWT-DDTFA method. Acta Geophysica Sinica, 61(10), 40634074. doi:10.6038/cjg2018L0431

Kuzmenko, E.D., Bagriy, S.M., Dzoba, U.O. (2018). The depth range of the Earth'snatural pulse electromagneticfield (or ENPEMF). Journal Of Geology Geography And Geoecology, 27, 3, 466-477. DOI: 10.15421/111870.

Malyshkov, Y. ., Malyshkov, S. . (2016). The algorithm for calculating the earth's core runs on the parameters of natural pulsed electromagnetic field of the earth. Paper presented at the IOP Conference Series: Earth and Environmental Science, 48(1). doi:10.1088/1755-1315/48/1/012028

\section{References}

Activation of hazardous exogenous geological processes according to monitoring EGP. (2019). State Service of Geology and Subsoil of Ukraine. Kyiv, XVI. Retrieved from http://www.geoinf.kiev.ua/SZHORICHNYK_2019.pdf [in Ukrainian]

Bagriy, S.M. (2016). Heofizychnyi monitorynh heolohichnoho seredovyshcha $v$ mezhakh rodovyshch kaliinoi soli (na prykladi Kalush-
Holynskoho rodovyshcha). Dis. ... Cand. Geol. Sciences: 04.00.22. IvanoFrankiv. nats. tekhn. un-t nafty i hazu, Ivano-Frankivsk. [in Ukrainian]

Belova, M., lakovleva, E., Popov, A. (2019). Mining and environmental monitoring at open-pit mineral deposits. Journal of Ecological Engineering, 20(5), 172-178. doi:10.12911/22998993/105438

Bessmertnyi, A.F. (2004). Kompleksnyye geofizicheskiye issledovaniya opolzney i postroyeniye prognoznykh modeley ikh aktivnosti (na primere Yuzhnogo berega Kryma). Dis. ... Cand. Geol. Sciences. Simferopol. [in Russian]

Cheban, V.D. (2002). Kompleks heofizychnykh metodiv prohnozuvannia zsuviv na prykladi Zakarpattia. Dis. ... cand. geol. sciences: 04.00.22. IvanoFrankivsk. [in Ukrainian]

Deshchytsia, S., Pidvirnyi, O., Romaniuk, O., Sadovyi, Yu., Koliadenko, V., Savkiv, L., Myshchyshyn, Yu. (2016). Otsinka stanu ekolohichno problemnykh obiektiv Kaluskoho hirnychopromyslovoho raionu elektromahnitnymy metodamy ta yikh monitorynh. Nauka innov., 12(5), 4759. [in Ukrainian]

Dodatko, A.D., Zmiyevskaya, K.O., Kozar, N.A. (2013). Detalization of tectonic features of the sergeyevskoye deposit by means of the method of natural impulse electromagnetic field of the earth. Naukovyi Visnyk Natsionalnoho Hirnychoho Universytetu, 1, 5-10.

Dolgii, M.E., Kataev, S.G. (2015). Issledovanie estestvennogo impulsnogo elektromagnitnogo polya Zemli. Vestn. Tomsk. gos. un-ta. Matem. i meh., 2(34), 61-70. DOI: https://doi.org/10.17223/19988621/34/6 [in Russian].

Dovbnich, M.M., Stovas, H.M., Kanin, V.O. (2012). Sposterezhennia PIEMPZ vertykalnoho hradiientu mahnitnoho polia Zemli na poli shakhty im. O.F. Zasiadka. Naukovi pratsi Ukr NDMI NAN Ukrainy, 10, 342-348. [in Ukrainian]

Hao, G., Bai, Y., Wu, M., Wang, W., Liu, H. (2018). Time-frequency analysis of the earth's natural pulse electromagnetic field before earthquake based on BSWT-DDTFA method. Acta Geophysica Sinica, 61(10), 40634074. doi:10.6038/cjg2018L0431

Ivanov, V.V., Tarasov, B.G., Kuzmenko, E.D., Gordiychuk, N.V. (1991). O geomekhanicheskoy prirode potentsialov elektricheskogo polya $\vee$ zemnoy kore. Izv. VUZov. Geologiya i razvedka, 3, 101-104. [in Russian]

Khmara, I.Ye., Kuzmenko, E.D., Bagriy, S.M. et al. (2008). Provedennia monitorynhovykh sposterezhen nad shakhtnymy poliamy Kalush-Holynskoho rodovyshcha kaliinykh solei. Science report. № DR 0108U007562, Inv. №0309U00296. Kalush: DP "NDI Halurhii". [in Ukrainian]

Kovalchuk, S.P. (2003). Postav svoy dom pravilno (Praktika geofizicheskogo metoda EIEMPZ). Odessa: Chernomorye. [in Russian]

Kuzmenko, E.D., Bagriy, S.M., Chepurnyi, I.V., Shtohryn, M.V. (2017). Otsinka nebezpeky prypoverkhnevykh deformatsii hirskykh porid u mezhakh Stebnytskoho kaliinoho rodovyshcha metodom PIEMPZ. Heodynamika, 1(22), 98-113. [in Ukrainian]

Kuzmenko, E.D., Bagriy, S.M., Dzoba, U.O. (2018). The depth range of the Earth'snatural pulse electromagneticfield (or ENPEMF). Journal Of Geology Geography And Geoecology, 27, 3, 466-477. DOI: 10.15421/111870.

Kuzmenko, E.D., Bezsmertnyi, A.F., Vdovyna, O.P., Kryviuk, I.V., Cheban, V.D., Shtohryn, L.V. (2009). Doslidzhennia zsuvnykh protsesiv heofizychnymy metodamy. Ivano-Frankivsk: IFNTUOG. [in Ukrainian]

Maksymchuk, V., Sapuzhak, O., Deshchytsia, S., Ladanivskyi, B., Romaniuk, O., Koliadenko, V. (2019). Doslidzhennia karstoprovalnykh protsesiv na terytorii Stebnytskoho rodovyshcha kaliinykh solei metodamy elektrorozvidky. Heoforum-2019. Zbirnyk tez dopovidei 24-yi Mizhnarodnoi naukovo-tekhnichnoi konferentsii, Lviv, 37-38. [in Ukrainian]

Malyshkov, Y.P., Malyshkov, S.Y. (2016). The algorithm for calculating the earth's core runs on the parameters of natural pulsed electromagnetic field of the earth. Paper presented at the IOP Conference Series: Earth and Environmental Science, 48(1). doi:10.1088/1755-1315/48/1/012028

National report on the state of technogenic and natural safety in Ukraine in 2012. (2013). State Service "Ahentstvo "Chornobylinform". [in Ukrainian]

Salomatin, V.N., Mastov, Sh.R., Zaschinskiy, L.A. (1991). Metodicheskiye rekomendatsii po izuchenniyu napryazhenogo sostoyaniya porod metodom registratsii estestvennogo impulsnogo elektromagnitnogo polya Zemli (EIEMPZ). Simferopol. [in Russian]

Shurovsky, O.D., Anikeev, S.G., Shamotko, V.I., Deshchytsia, S.A. (2013). Geofizicheskiy monitoring geologicheskoy sredyi dlya resheniya ekologicheskih problem v predelah aglomeratsii g. Kalusha. Gornyiy zhurnal, 12, 99-104. [in Russian]

Shurovsky, O.D., Anikeiev, S.H., Shamotko, V.I., Deshchytsia, S.A., Nikolaienko, O.A., Popliuiko, A.H. (2012). Heofizychnyi monitorynh ekonebezpechnykh heolohichnykh protsesiv $v$ ahlomeratsii $m$. Kalusha. Mineralni resursy Ukrainy, 2, 31-38.

Tarasov, B., Dyirdin, V., Ivanov, V. (1983). Geoelektricheskiy kontrol sostoyaniya massivov. Moskva: Nedra. [in Russian]

Vorobyov, A.A. (1971). Fizicheskie usloviya zaleganiya veschestva v zemnyih nedrah. Tomsk: Izd. Tomskogo universiteta. [in Russian]

Vorobyov, A.A. (1980). Ravnovesiye i preobrazovaniye energii v nedrakh. Tomsk: Izd. Tomskogo universiteta. [in Russian]

Надійшла до редколегії 13.09.19 
С. Багрій, канд. геол. наук

E-mail: gbg2020@ukr.net;

Е. Кузьменко, д-р геол.-мінералог. наук, проф.,

E-mail: kuzmenko.eduard@gmail.com;

у. Дзьоба, асист.

E-mail: ulianadzoba@gmail.com;

Івано-Франківський національний технічний університет нафти і газу,

Інститут природничих наук і туризму,

вул. Карпатська, 15, м. Івано-Франківськ, 76019, Україна

\title{
ЗВ'ЯЗОК ПРИРОДНОГО ІМПУЛЬСНОГО ЕЛЕКТРОМАГНІТНОГО ПОЛЯ ЗЕМЛІ 3 НАПРУЖЕННЯМИ ТА ДЕФОРМАЦІЯМИ ГІРСЬКИХ ПОРІД НА ВІДПРАЦЬОВАНИХ РОДОВИЩАХ СОЛІ В ПЕРЕДКАРПАТТІ В ЗАДАЧАХ ПРОГНОЗУВАННЯ РОЗВИТКУ КАРСТУ
}

\begin{abstract}
У даний час актуальним є питання вирішення еколого-геологічних проблем, які виникають у результаті відпрацювання природних ресурсів, зокрема родовищ калійних солей. Специфічність полягає у легкій розчинності солей $i$, отже, у створенні штучних порожнин $i$ карстових явищ. Розглянуто шляхи вирішення проблем картування соляного карсту та прогнозування провалів і осідань земної поверхні на прикладі Калуш-Голинського родовища калійної солі, що знаходиться в Українському Прикарпатті. Як основи дослідницького комплексу були розглянуті геофізичні методи. Доведено, що для достовірної оцінки напружено-деформованого стану гірських порід і відповідно для прогнозування карстових процесів і деформацій, пов'язаних із наявністю видобувних камер і розвитком карсту, можна успішно застосовувати метод природного імпульсного електромагнітного поля Землі (ПІЕМПЗ). Розглянуто фбізичні передумови застосування методу, викладено основні постулати класифікації аномалій напруженості поля, розроблено підхід для оцінки глибинності. У реальних прикладах показано результати профільних та площинних досліджень у межах калійного родовища солі, які свідчать про ефективність методу ПІЕМПЗ для вирішення еколого-геологічних задач.

Ключові слова: еколого-геологічна проблема, геофізичні методи дослідження, родовища солі, природне імпульсне електромагнітне поле Землі, карст, осідання земної поверхні.
\end{abstract}

\section{С. Багрий, канд. геол. наук}

E-mail: gbg2020@ukr.net;

Э. Кузьменко, д-р геол.-минералог. наук, проф.,

E-mail: kuzmenko.eduard@gmail.com;

у. Дзьоба, ассист.

E-mail: ulianadzoba@gmail.com;

Ивано-Франковский национальный технический университет нефти и газа,

Институт природоведческих наук и туризма,

ул. Карпатская, 15, г. Ивано-Франковск, 76019, Украина

\section{СВЯЗЬ ЕСТЕСТВЕННОГО ИМПУЛЬСНОГО ЭЛЕКТРОМАГНИТНОГО ПОЛЯ ЗЕМЛИ С НАПРЯЖЕНИЯМИ И ДЕФОРМАЦИЯМИ ГОРНЫХ ПОРОД НА ОТРАБОТАННЫХ МЕСТОРОЖДЕНИЯХ СОЛИ В ПРИКАРПАТЬЕ В ЗАДАЧАХ ПРОГНОЗИРОВАНИЯ РАЗВИТИЯ КАРСТА}

В настоящее время актуальным является решение экологических и геологических проблем, возникающих в результате отработки природных ресурсов, в частности месторождений калийных солей. Специфика заключается в легкой растворимости солей и, следовательно, в создании искусственных полостей и карстовых явлений. Ррассматриваются способы решения задач картирования солевого карста и прогнозирования образования провалов и оседаний земной поверхности на примере Калуш-Голынского месторождения калийной соли, которое находится в Прикарпатье. В качестве основы исследовательского комплекса были рассмотрены геофизические методы. Доказано, что для надежной оценки напряженно-деформированного состояния горных пород и, соответственно, для прогнозирования карстовых процессов и деформаций, связанных с наличием добывающих камер и развитием карста, можно успешно применять метод естественного импульсного электромагнитного поля Земля (ЕИЭМПЗ). Описаны физические предпосылки применения метода, изложены основные постулаты классификации полей аномалий напряженности поля, разработан подход к оценке глубинности. На реальных примерах показаны результаты профильных и площадных исследований в пределах калийного месторождения соли, которые свидетельствуют об эффективности метода ЕИЭМПЗ для решения экологических и геологических задач.

Ключевые слова: эколого-геологическая проблема, геофизические методы исследования, залежи соли, природное импульсное электромагнитное поле Земли, карст, оседание земной поверхности. 